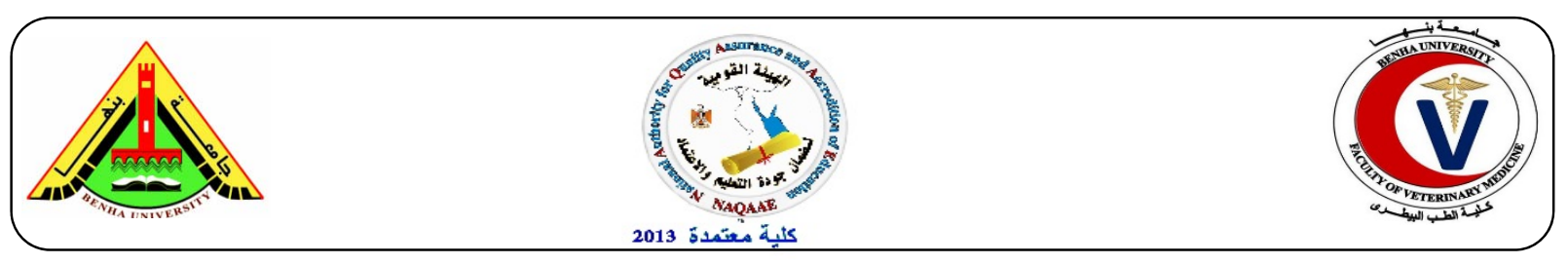

\title{
Evaluation the effect of Lactobacillus acidophilus probiotic culture over Staphylococcus aureus during the production and storage of acidophilus yoghurt
}

\author{
Huda E. Othman'; Hamdi M. Abdelsamei²; Adham M. Abdou. ${ }^{2}$; Ekbal M. A. Ibrahim² and \\ Azza, H. Elbaba. ${ }^{1}$ \\ ${ }^{1}$ Food Hygiene Department, Animal Health Research Institute, ARC, Dokki, Giza, Egypt. \\ ${ }^{2}$ Milk Hygiene, Department of Food Control, Fac. of Vet. Med., Benha Univ., Egypt
}

\section{A B S T R A C T}

The survival of Staphylococcus aureus in the acidophilus yoghurt (AY) was evaluated during the production and cold storage. 21 acidophilus yoghurt samples were prepared with traditional yoghurt culture (Streptococcus thermophiles \& Lactobacillus bulgaricus) with Lactobacillus acidophilus and inoculated with $10^{6} \mathrm{cfu} / \mathrm{ml}$ S. aureus and stored for 21 days at $4^{\circ} \mathrm{C}$. Samples were taken at zero time (fresh samples), 3, 5, 7, 10, 14 and 21 days for titratable acidity, culture starters' counts and S. aureus count. The results revealed that the titratable acidity $\%$ of AY was increased and reached $0.72,0.78$, $0.83,0.87,0.89,1.02$ and $1.45 \%$ at zero time, $3,5,7,10,14$, and 21 days of storage, respectively, while the population of $S$. aureus reached 6.10 and $3.70 \log _{10} \mathrm{cfu} / \mathrm{g}$ at zero time and $3^{\text {rd }}$ day of storage, respectively and became non-detectable level in $5^{\text {th }}$ days of storage. The count of all starter cultures (S. thermophiles + L. bulgaricus + L. acidophilus) in acidophilus yoghurt increased during the fermentation and cold storage, $S$. thermophiles became 7.15, 7.35, 8.20, 8.15, 7.45, 7.45 and $6.65 \log _{10} \mathrm{cfu} / \mathrm{g}$ while L. bulgaricus $7.25,7.55,8.25,8.73,7.76,7.47$ and $6.54 \log _{10} \mathrm{cfu} / \mathrm{g}$ and L. acidophilus became 7.38 , $7.70,8.25,8.20,7.50,7,46$ and $6.66 \log _{10} \mathrm{cfu} / \mathrm{g}$ at zero time, $3,5,7,10,14$, and 21 days of storage, respectively. It concluded that $S$. aureus count decreased gradually during the production and cold storage and became non-detectable level on the $5^{\text {th }}$ days of cold storage. The survival of all starter cultures in yoghurt sample remained stable with values $>$ $6 \log _{10} \mathrm{cfu} / \mathrm{g}$ throughout the storage period at $4 \pm 1^{\circ} \mathrm{C}$.

Keywords: probiotic, lactobacillus acidophilus, S. aureus, yoghurt, acidophilus yoghurt.

(http://www.bvmj.bu.edu.eg)

(BVMJ-32(1): 127-131, 2017)

\section{INTRODUCTION}

Lactobacillus acidophilus is a probiotic microorganism available in conventional food (milk, yoghurt and toddler formula) and dietary supplements. It is well known that Lactobacillus acidophilus has health promoting effects, including immunomodulation, alleviation of lactose intolerance, antitumour, hypochlolesterolemic effect and anti-infection properties. Antagonistic activity of $L$. acidophilus against food borne disease agents such as E. coli, S. aureus, S. typhimurium, L. monocytogenes and $\mathrm{Cl}$. perfringens has been previously reported (Kasimoglu and Akgun, 2004). "Probiotics" are defined as" live microorganisms which when administered in adequate amounts (between $10^{6}$ $10^{7} \mathrm{cfu} / \mathrm{g}$ ) confer a health benefit on the host" (FAO/WHO, 2010). Lactobacillus and Bifidobacterium spp. are the most commonly used as probiotics. Some dairy products, as fermented milk have been used as a carrier food for probiotic bacteria (Bergamini et al., 2005; El-Kholy et al., 2014). S. aureus is Gram- positive bacteria and it is a causative agent of bovine mastitis capable of producing thermostable enterotoxins. Food-borne illness due to $S$. aureus can cause abdominal cramps, nausea, vomiting, and diarrhoea (Bennett, 2012). S. aureus is a common environmental microorganism which is found in raw milk (Jackson et al., 2012). Temperature abuse above $10^{\circ} \mathrm{C}$ and poor starter cultures activity during fermentation are factors involved in dairy-related outbreaks of staphylococcal intoxication (Cretenet et al., 2011; Juan et al., 2015). In previous studies, the $S$. aureus has been shown to survive in yoghurt stored at $4^{\circ} \mathrm{C}$ from few days to several weeks (Bachrouri et al., 2002; Halawa and Abou Zeid, 2000).

The present study aimed to evaluate the antagonistic activity of $L$. acidophilus on S. aureus 
counts and examine the survival of starter cultures in acidophilus yoghurt sample during the production and cold storage.

\section{MATERIALS AND METHODS}

2.1. Yoghurt cultures (were obtained from Chr. Hansen Lab., Copenhagen, Denmark):

Acidophilus yoghurt starter cultures contain Streptococcus thermophiles \& Lactobacillus delbrueckiisubspp. bulgaricus $(1.5 \%)+$ Lactobacillus acidophilus strain La-5 (1.5\%) and were prepared according to Hull and Robert (1984).

\subsection{S. aureus NCTC 7447/ ATCC® 6538P}

It was obtained from Becton Dickinson, France) and activated at Food Hygiene department- Animal Health Research Institute- Dokki, Giza, Egypt. It was prepared according to Bachrouri et al. (2002).

\subsection{Preparation of acidophilus yoghurt samples: according to Nighswonger et al. (1996).}

\subsection{Determination of titratable acidity (T.A).}

\subsection{Microbiological examination:}

Yoghurt samples were taken at Zero time, 3, 5, 7, 10,14 and 21 days of cold storage $\left(4 \pm 1^{\circ} \mathrm{C}\right)$, thoroughly mixed aseptically immediately after opening of yoghurt cup, and from each prepared samples, 10 folds serial dilutions were prepared according to A.P.H.A. (American Public Health Association) (2001) for the count of the following: $S$. thermophiles according to Shanker and Davies (1977), L. bulgaricus according to Kailasapathy et al. (2008) and L. acidophilus according to (Tharmaraj and Shah, 2003). S. aureus according to APHA (2001).

\subsection{Statistical analysis: Data were analyzed by using SPSS (2000)}

\section{RESULTS}

This study aimed to evaluate the antagonistic activity of L. acidophilus on S. aureus counts and examined the survival of starter cultures in acidophilus yoghurt sample during the production and cold storage.

Titratable acidity $\%$ of AY was increased and reached $0.72,0.78,0.83,0.87,0.89,1.02$ and $1.45 \%$ at zero time, $3,5,7,10,14$, and 21 days of storage, respectively (Table 1). The population of S. aureus increased and reached $6.10 \log _{10} \mathrm{cfu} / \mathrm{g}$ at zero time then decreased to $3.70 \log _{10} \mathrm{cfu} / \mathrm{g}$ at the $3^{\text {rd }}$ day of storage and became non-detectable level in $5^{\text {th }}$ days of storage (Table 2).

The count of all starter cultures ( $S$. thermophiles $+L$. bulgaricus $+L$. acidophilus) in acidophilus yoghurt which increased during the fermentation and cold storage, S. thermophiles became $7.15,7.35,8.20,8.15,7.45,7.45$ and 6.65 $\log _{10} \mathrm{cfu} / \mathrm{g}$ while L. bulgaricus $7.25,7.55,8.25$, 8.73, 7.76, 7.47 and $6.54 \log _{10} \mathrm{cfu} / \mathrm{g}$ and $L$. acidophilus became 7.38, 7.70, 8.25, 8.20, 7.50, 7,46 and $6.66 \log _{10} \mathrm{cfu} / \mathrm{g}$ at zero time, $3,5,7,10$, 14, and 21 days of storage, respectively (Fig. 1).

Table (1): The mean values of titratable acidity in prepared acidophilus yoghurt samples during refrigerated storage (mean $\pm \mathrm{SD}$ )

\begin{tabular}{ll}
\hline Samples & AY \\
\hline Zero & \\
3 & $0.72 \pm 0.01$ \\
5 & $0.78 \pm 0.03$ \\
7 & $0.83 \pm 0.01$ \\
10 & $0.87 \pm 0.02$ \\
14 & $0.89 \pm 0.01$ \\
21 & $1.02 \pm 0.01$ \\
\hline
\end{tabular}

AY: Acidophilus yoghurt S: Spoilage of sample by visualized mould growth

Table (2): Viability of S. aureus (mean $\log _{10} \mathrm{cfu} / \mathrm{g}$ ) in the AY samples during their refrigerated storage

\begin{tabular}{lllllll}
\hline Yoghurt & \multicolumn{6}{c}{ Days of storage } \\
sample & 0 & 3 & 5 & 7 & \\
& & & & & \\
\hline AY & 6.10 & 3.70 & $<1$ & & $<1$ \\
\hline
\end{tabular}

AY: Acidophilus yoghurt 


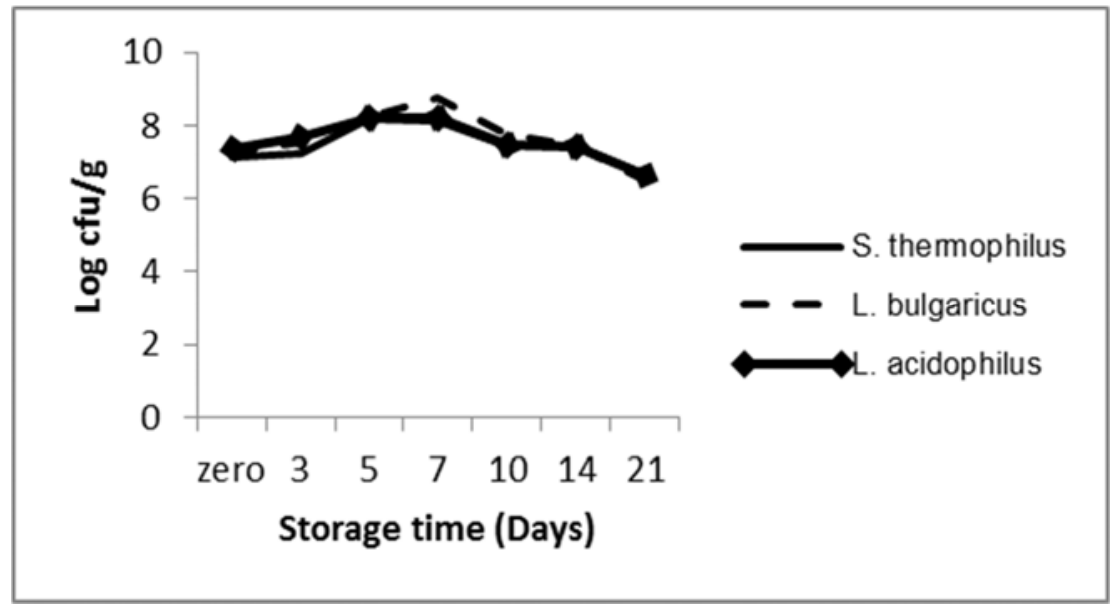

Fig. (1): The mean counts of S. thermophilus, L. bulgaricus and L. acidophilus counts in the acidophilus yoghurt samples throughout their refrigerated storage.

\section{DISCUSSION}

Titratable acidity (TA) is commonly used to estimate the milk freshness milk and to monitor the production of lactic acid during fermentation (ElKholy et al., 2014). Bacteria that normally develop in raw milk produce more or less of lactic acid. In acidity, test the acid is neutralized with $0.1 \mathrm{~N}$ Sodium Hydroxide and the amount of alkaline is measures. From this, the percentage of lactic acid can be calculated, fresh milk contains natural acidity which due to natural ability to resist $\mathrm{pH}$ changes. The natural acidity of milk is $0.16-0.18 \%$ and yoghurt is $0.70-0.80 \%$, acidification of milk is primarily depending on conversion of Lactose into organic acids which lower the $\mathrm{pH}$ of milk from a value of 6.8 or less than 4.7. Thus protecting the fermented milk against the risk of contamination by different pathogens and making it hygienically safe (Al-Kadamany et al., 2002).

Data represented in Table (1) illustrated the changes of acidity during the samples showed significant increase during the storage time (AY) samples showed the high titratable acidity value due to that the fermentation resulted in increasing the T.A\%, the kind of probiotic culture and incubation temperature significantly affect the acidity of these samples $(P<0.05)$; In selection of starter culture and probiotic bacteria ( $L$. acidophilus), for production fermented products, ability of acid production in short time is the important factor. The acidification in acidophilius yoghurt depends on the growing of microorganisms and their ability for fermentation of the lactic acid (Rahnama-Fatemeh et al., 2013). According to Patricia and Salvador (2006) L. acidophilus with traditional yoghurt starter culture produced the lactic acid during fermentation and storage, and L. acidophilus produced additionally to lactic acid other acids like acetic acid, during the storage period. During the 21 days of the storage period, generally the yoghurt showed increasing titratable acidity. These results agreed with those obtained by El-Kholy et al. (2014) and Horáčková et al. (2015). Results showed in table (2) represented the viability of $S$. aureus during production and storage of acidophilus, the count decreased to undetectable limit in 5 days of storage. Similar results were obtained by Abdel-Aziz-Mona (2011); Awad (2011); Lengkey and Adriani (2009)- and Meawad-Marwa (2011).

The viability of probiotic bacteria in yoghurt must kept sufficiently high to ensure that consumers receive health benefits. These benefits include the prevention of diarrhea, balancing of intestinal microflora, stimulation of the immune system, antitumor properties and alleviation of lactose tolerance (El-Kholy et al., 2014; Guktepe, 2006). Of particular importance, is the capacity of probiotics to antagonize pathogens (TejeroSarinena et al., 2012). In order to produce these benefits, It is important to note that the number of lactic acid bacteria present in different systems of yoghurt was constant over time, as it kept in a range of $10^{6}$ to $10^{8} \mathrm{CFU} / \mathrm{g}$, which is the need to exercise bactericidal action as well as being the recommended number by FAO/WHO (2010) as the amount of bacteria needed for exercising beneficial effects on the body (Gueimonde et al., 2004).

The changes in the viable counts of $S$. thermophilus, L. bulgaricus and L. acidophilus in yoghurt during manufacture and storage are given in Fig. (1), it is clear that the log of all starter cultures slightly increased till the $5^{\text {th }}$ and the $7^{\text {th }}$ days and then decreased slowly to the end of the storage 
period. Survival of starters and probiotic in yoghurt was satisfactory and the microbial counts remained stable with values around $6-8 \quad \log _{10} \mathrm{cfu} / \mathrm{ml}$ throughout the storage period. Similar observations were reported by Abd El-Gawad et al. (2014); ElKholy et al. (2014); Mani-López et al. (2014); Ranasinghe and Perera (2016). After 21 days of storage at $4 \pm 1^{\circ} \mathrm{C}$, the yoghurt still contained 6.65 , 6.51 and $6.66 \log _{10} \mathrm{cfu} / \mathrm{g}$ of $S$. thermophiles, $L$. bulgaricus and $L$. acidophilus respectively, thus satisfying the criteria for probiotic bacteria. Donkor et al. (2007) concluded that the ability of probiotic to survive in yoghurt was strain dependent, in addition L. acidophilus could survive in yoghurt at sufficient levels $\left(>10^{6} \mathrm{cfu} / \mathrm{g}\right)$ for up to 28 days. Variation in the probiotic viability data among different authors may probably be attributed to strain variation, acid accumulation, interaction with starter cultures and storage condition. Zhang et al. (2016) found that Lactobacillus spp. are good probiotic candidates, help to promote health of hosts, protect hosts from intestinal pathogens and maintain the natural balance of intestinal microflora during antibiotic treatments. The data suggested that yoghurt can be a suitable carrier food to supply consumers with Lactobacilli having potential health and nutritional benefits (Juan et al., 2015)

\section{CONCLUSION}

The results in this study demonstrated the capability of the selected probiotic bacteria to inhibit the growth of S. aureus in- vitro. Survival of L. acidophilus in yoghurt was satisfactory as it remained viable at levels $>10^{6} \mathrm{cfu} / \mathrm{g}$ after 21 days of storage at $4 \pm 1{ }^{\circ} \mathrm{C}$, which indicate that the yoghurt would be a suitable vehicle for probiotic bacteria. L. acidophilus has been shown to possess inhibitory activity toward the growth of $S$. aureus during the fermentation and storage of acidophilus yoghurt, as the presence of pathogenic bacteria as $S$. aureus pose a risk for public health. Therefore, the hygienic standard needs to be strengthened during manufacture and storage to ensure production of safe, high quality yoghurt.

\section{REFERENCES}

A.P.H.A. (American Public Health Association), 2001. Compendium of methods for the microbiological examination of foods. . $4^{\text {th }}$ Ed. Amer. Public Health Asso., Washington, D.C., USA.

Abd El-Gawad, I.A., El-Sayed, E.M., El- Zeini, H.M., Hafez, S.A., Saleh, F.A., 2014.
Antibacterial activity of probiotic yoghurt and soy-yoghurt against Escherichia coli and Staphylococcus aureus. Nut. Food Sci. 4, 16.

Abdel-Aziz-Mona, M.M., 2011. The role of Bifidobacteria in improvement of physical, chemical and microbial quality of fermented dairy products. PhD Thesis. Benha Univ. Faculty of Vet. Med.

Al-Kadamany, E., Toufeili, I., Khattar, M., AbouJawadeh, Y., Harakch, S., Haddad, T., 2002. Determination of shell life of concentration yoghurt (labneh) produced by in-Bag straining of set yoghurt using Hazard Analysis. J. Dairy Sci. 85, 1030-1023.

Awad, M.M., 2011. Effect of bacterocins produced by some lactic acid bacteria on the quality of yoghurt. MVSc. Thesis, Faculty of Vet. Med. Benha University, Egypt.

Bachrouri, M., Quinto, E.J., Mora, M.T., 2002. Survival of Escherichia coli O157:H7 during storage of yoghurt at different temperatures. J. Food Sci 67, 1899-1903.

Bennett, R., 2012. Staphylococcus aureus," in Bad Bug Book. Foodborne Pathogenic Microorganisms and Natural Toxins, K. A. Lampel, S. Al-Khaldi and S. M. Cahill, Eds., 87-92. US Food and Drug Administration (FDA), Silver Spring, Md, USA, $2^{\text {nd }}$ ed.

Bergamini, C.V., HYnes, E.R., Quiberoni, A., Suarez, V.B., Zalazar, C.A., 2005. Probiotic bacteria as adjunct starters: influence of the addition methodology of their survival in semi-hard Argentinean cheese. Food Res. Int. 38, 597-604.

Cretenet, M., Even, S., LeLoir, Y., 2011. Unveiling Staphylococcus aureus enterotoxin production in dairy products: a review of recent advances to face new challenges. Dairy Sci. and Tech. 91, 127-150.

Donkor, O.N., Henriksson, A., Vasiljevic, T., Shah, N.P., 2007. Effect of acidification on the activity of probiotics in yoghurt during cold storage. Int Dairy J 16, 1181-1189.

El-Kholy, A.M., El-Shinawy;, Meshref, A.M.S., Korny, A.M., 2014. Screening of antagonistic activity of probiotic bacteria against food-borne pathogens. J. of App. \& Enviro. Microbiolo 2, 53-60.

FAO/WHO, 2010. Codex standard for fermented milks ( $2^{\text {nd }}$ ed.). Codex Stan 243-2003.

Gueimonde, M., Delgado, S., Mayo, B., RuasMadiedo, P., Margolles, A., Reyes-Gavilan, C.G., De, 1., 2004. Viability and diversity of probiotic Lactobacillus and Bifidobacterium 
populations included in commercial fermented milks. Food Res Int. 37, 839-850.

Guktepe, I., 2006. Probiotics as bio-preservatives for enhancing the food safety. In Goktepe, I., Juneja, V. K. and Ahmedna, M. ed., Probiotics in food safety and human health. CRC, Taylor and Fracis group 285-307.

Halawa, M.A., Abou Zeid, A.M., 2000. Behavior of enterohemorrhagic Escherichia coli and Enterotoxigenic Staphylococcus aureus in yoghurt and acidified milk. Vet. Med. J. Giza, 48, 319-326.

Horáčková, Š., Mühlhansová, A., Sluková, M., Schulzová, V., Plocková, M., 2015. Fermentation of soymilk by yoghurt and Bifidobacteria Strains. Czech J. Food Sci. 33, 313-319.

Hull, R.R., Robert, A.V., 1984. Differential enumeration of Lactobacillus acidophilus in yoghurt. Journal Aust. Dairy technology 3, 160-164.

Jackson, E.E., Erten, E.S., Maddi, N.M., 2012. Detection and enumeration of four foodborne pathogens in raw coming led silo milk in the United States. J. of Food Prot. 75, 1382-1393.

Juan, L.A., Eva, R., Susana, L., José, M.L., Margarita, M., 2015. Antimicrobial Activity of Lactic Acid Bacteria in Dairy Products and Gut: Effect on Pathogens. Review. BioMed Res. Int. Article ID 584183: 9 pages.

Kailasapathy, K., Harmstorf, I., Phillips, M., 2008. Survival of Lactobacillus acidophilus and Bifidobacterium animalis ssp. lactis in stirred fruit yogurts. Food Sci. Tech. 42, 1317-1322.

Kasimoglu, A., Akgun, S., 2004. Survival of Escherichia coli $\mathrm{O} 157: \mathrm{H} 7$ in the processing and post-processing stages of acidophilus Yoghurt. Int. J. Food Sci. Tech. 39, 563-568.

Lengkey, H.A.W., Adriani, L., 2009. Effect of milk fermented with Lactobacillus acidophilus and Bifidobacterium spp. on lactic acid and acetic acid content on Staphylococcus aureus and Pseudomonas aeruginosa. Biotechnology in Animal Husbandry 25, 719-724.

Mani-López, E., Palou, E., López-malo, A., 2014. probiotic viability and storage stability of yogurts and fermented milks prepared with several mixtures of lactic acid bacteria. J. Dairy Sci. 97, 2578-2590.
Meawad-Marwa, A.M., 2011. Effect of bacteriocins produced by some lactic acid bacteria on the quality of yoghurt. MD Thesis. Benha University.

Nighswonger, B.D., Brashears, M.M., Gilliland, S.E., 1996. Viability of Lactobacillus acidophilus and Lactobacillus casei in fermented milk products during refrigerated storage. J Dairy Sci 79, 212-219.

Patricia, B.Z., Salvador, M.-R., 2006. Properties of Streptococcus thermophiles fermented milk containing variable concentraction of Bifidobacteriumlongum and Lactobacillus acidophilus. Brazelian J. of Microbio. 37, 338-344.

Rahnama-Fatemeh, Rezvan, P., Zahra, P.V., 2013. Production of probiotic soy-yogurt containing conjugated linoleic acid. Annals of Biological Research 4, 182-187.

Ranasinghe, J.G.S., Perera, W.T.R., 2016. Prevalence of Lactobacillus bulgaricus and Streptococcus thermophilus stability in commercially available yogurts in Sri lanka. Asian J. of Med. Sci. 7, 97-10.

Shanker, R.A., Davies, F.L., 1977. Recent developments in yoghurt starters 2. A note on the suppression of lactobacillus bulgaricus in media containing Bglycerophosphate and application of such media to selective isolation of Streptococcus thermophilus from yoghurt. J. The Society of Dairy Tech. 30, 28-30.

Tejero-Sarinena, S., Barlow, J., Costabile, A., Gibson, G.R., Roland, J., 2012. In vitro evaluation of the antimicrobial activity of a range of probiotics against pathogens. Evidence for the effects of organic acids. Anaerobe 18, 530-535.

Tharmaraj, N., Shah, N.P., 2003. Selective enumeration of Lactobacillus delbrueckii ssp. bulgaricus, Streptococcus thermophilus, Lactobacillus acidophilus, bifidobacteria, Lactobacillus casei, Lactobacillus rhamnosus, and propionibacteria. J Dairy Sci 86, 2288-2296.

Zhang, B., W.;, Y., Zhongfang, T., Zongwei, L., Zhen, J., Qunce, H., 2016. Screening of probiotic activities of Lactobacilli strains isolated from traditional Tibetan Qula, a raw Yak milk cheese. Asian Austral. J. Anim. Sci. 29, 1490-1499. 